\title{
The application of tahawwul (transformation) process for determination of vinegar status in the Malaysia market
}

\author{
${ }^{1,3 *}$ Harahap, I., ${ }^{2}$ Shukri, A.S.M., ${ }^{1}$ Jamaludin, M.A., ${ }^{3}$ Nawawi, N., ${ }^{3}$ Alias, R. and \\ ${ }^{4}$ Zaharim, A. \\ ${ }^{1}$ International Institute for Halal Research and Training (INHART), International Islamic University \\ Malaysia (IIUM), Jalan Gombak, 53100, Kuala Lumpur, Malaysia. \\ ${ }^{2}$ Kulliyah of Islamic Revealed Knowledge and Human Science (KIRKHS), International Islamic University \\ Malaysia (IIUM), Jalan Gombak, 53100, Kuala Lumpur, Malaysia. \\ ${ }^{3}$ Centre for Foundation and General Studies, Universiti Selangor, Bestari Jaya Campus, Jalan Timur \\ Tambahan, 45600 Bestari Jaya, Selangor Darul Ehsan, Malaysia. \\ ${ }^{4}$ Department of Engineering Education Faculty of Engineering and Built Environment, Universiti \\ Kebangsaan Malaysia (UKM) 43600 UKM, Bangi Selangor, Malaysia.
}

\begin{abstract}
Article history:
Received: 28 November 2019

Received in revised form: 14

January 2020

Accepted: 18 January 2020

Available Online: 22

February 2020
\end{abstract}

Keywords:

Vinegar,

Alcohol,

Acetic acid,

Ḥalāl,

Ḥarām,

Tahawwul.

DOI:

https://doi.org/10.26656/fr.2017.4(3).393

\section{Introduction}

Islam had stated that every food that consumed by Muslim must be halālan tayyiban. There are vast aspects when it comes to halāl in contrast to harām which are little and very limited (Al-Ghazālī, 2006). Although the halāl things are more extensive than of harām, there are other aspects that are still unclear of its halāl status; such as vinegar that contains alcohol. The presence of alcohol in food or beverages is a much-debated issue among consumers; due to the trace of alcohol in the food or beverages that are very much associated to the halāl status (Riaz, 1997). Alcohol is a chemical compound that could cause intoxication when consumed over the allowed limit. It is categorized as harām (forbidden) in the Islamic teachings regardless of the size of the intakes (Najiha and Wan Nadiah, 2014). Alcohol had existed for a very long time in food and beverages (Deedat, 1991) especially the ones that are produced through the fermentation process. However, in sharia law, there is a purification process of something that is harām to become halāl and it is called as tahawwul. Tahawwul can be asserted as a phase or transfer, which is the change of a hukm to another hukm with the clear reason (AlTahānawī, 1996) in other words tahawwul could mean a change of a form to another which may bring effect on the status of a particular hukm (Wizārat al-Awqāf Wa Shuūn al-Islāmiyyah al-Kuwait, 1983). Tahawwul also means a change of substance to something else (Amsīwit, 2016) which includes the physical exchange and its nature (Al-Zuhaylī, 1985) such as the change of unclean (najs) being clean, such as the transformation of blood into milk or the transformation of khamr into vinegar. Naturally, every product that is produced through the fermentation process would consist of alcohol either in a big or small percentage. This is because the alcohol or specifically ethanol will form through the fermentation of fruits, cereals and starch with the aid of yeast (Zohri and Etnan, 2000).

Alcohol can be produced through the fermentation process either naturally or industrially. Through the fermentation process, there are several products that can be produced namely juice, nabidh, khamr and vinegar. 
Every product that is produced through the process of fermentation, will also have different $h u k m$ namely halāl, harām and shubhah. The difference in the hukm happened because of the presence of alcohol in the products produced, besides the fermentation period in the manufacturing stage of a product such as vinegar. This can also determine the legal status and hukm of the vinegar product. The fermentation period determines the variety of vinegar produced, but generally, the vinegar produced through the traditional process takes a much longer time than the fermentation period in producing the modern-day nabidh, khamr and vinegar (Ghanem, 2014), some of which are produced through natural processes requires a longer fermentation period; between five and six weeks (Hailu et al., 2012) while the other types of vinegar require a longer period of fermentation that could go up to 40 days to 3 months depending on the type of vinegar and its source. This might also take a longer period and could reach up to a year. Vinegar produced through the traditional process is said to be of superior quality as compared to the vinegar produced through the modern process. This is because the traditionally processed vinegar will undergo the converting process from substances that contains sugar and requires a much longer period of time. The slow conversion process from natural ingredients will produce a higher quality of vinegar. The vinegar processed in this way is usually more flavorful and tastes better than the fast produced vinegar (Orey, 2009).

However, as the demand for high-grade vinegar products grows, some manufacturers have marketed their vinegar products even though they have not yet reached the mature fermentation or tahawwul sahịh process. Tahawwul is the purification method which turns something that is originally tăhir (clean) to become najs (unclean) and to tâhir (clean) again as in the making of vinegar (Wizārat al-Awqāf Wa Shuūn al-Islāmiyyah alKuwait, 1983). The vinegar that is produced before the tahawwul sahịh are mainly considered as a low-quality vinegar. Apart from that, the alcohol content that is still in the process of turning into vinegar is diminutive, resulting in a high alcohol content that could implicate to the harām status of the vinegar. The vinegar that is produced through a tahawwul sahinh will not only be a high-quality vinegar but it is also guaranteed to be halālan tayyiban and free from alcohol.

Therefore, this study is aimed to identify the halāl status of vinegar in the Malaysian market by using the concept of tahawwul or transformation as an alternate determination of the halāl status of vinegar. This is by looking at the alcohol content and acetic acid that exists in the final product of the vinegar using a scientific approach. It is common to know that vinegar is produced through a double fermentation process involving takhammur or the conversion of carbohydrates or sugars to alcohol and takhallul or the alcohol conversion into acetic acid (Jamaludin et al., 2017). Therefore, by studying the final product of vinegar found in the Malaysian market, it is possible to identify whether the vinegar products are halāl or harām or whether the vinegar is considered shubhah.

\section{Materials and methods}

\subsection{Materials}

A total of twenty-five kinds of vinegar were acquired from different places in the Malaysian market. All of the samples are as stated in Table 1.

Standard acetic acid at 1, 10, 30, 50 and 70 ppm was used to produce a calibration curve in order to determine the acetic acid concentration in commercial vinegar.

\subsection{Sample preparation}

A total of $4 \mathrm{~mL}$ of vinegar sample was transferred in a glass vial and $25 \mathrm{ppm}$ of IPA was added as an internal standard for ethanol content analysis. Then, $250 \mu \mathrm{L}$ samples were mixed with $1 \mathrm{~mL}$ of $2500 \mathrm{ppm}$ acetonitrile as an internal standard to make the Internal Standard concentration become $50 \mathrm{ppm}$. Then the mixture is added with distilled water to reach $50 \mathrm{~mL}$ in the volumetric flask. Before the samples are ready to be injected, the mixture was shaken for about $10 \mathrm{~s}$ to homogenize the mixture. After that, $500 \mathrm{uL}$ of $5000 \mathrm{ppm}$ sample was transferred into a vial and the sample was then injected into the GC-TOF/MS automatically by using the auto sampler sample injection. The steps were then repeated up to three times to ensure the results are fixed and consistent.

\subsection{Analysis of ethanol content}

An analysis of the ethanol content in every sample of vinegar out using gas chromatography (Shimadzu GC 2014) attached with the Flame Ionization Detector (HSGC-FID) with Head Space Analyzer (HS-10). The analysis was performed in duplicate. The percentage of ethanol content was obtained from the chromatogram produced. A Headspace Sampler (HS-10) Gas chromatograph coupled with flame ionization detector (GC FID-2014) Shimadzu Corporation Japan was employed in this study.

\subsection{Analysis of acetic acid content}

The acetic acid content was performed using the Gas Chromatography (GC) with Time of Flight Mass Spectrometry (TOF-MS) (Leco, St. Joseph, MI, USA). In this study, GC-TOF/MS was performed using an Agilent 
Table 1. List of 25 vinegar samples tested in the study

\begin{tabular}{|c|c|c|c|c|}
\hline Sample ID & Names and types of vinegar & $\begin{array}{l}\text { Categories of } \\
\text { vinegar }\end{array}$ & Original country & Status Logo \\
\hline V1 & Palm Vinegar (Cuka Nipah) & $\begin{array}{c}\text { Traditional/ } \\
\text { Natural }\end{array}$ & Malaysia & Non-Halal Logo \\
\hline $\mathrm{V} 2$ & Pak Man Warisan Tradisi Palm Vinegar (Cuka Nipah) & $\begin{array}{c}\text { Traditional/ } \\
\text { Natural }\end{array}$ & Malaysia & Non-Halal Logo \\
\hline V3 & Ikhwan Synthetic (Artificial Vinegar) & Industry & Malaysia & Non-Halal Logo \\
\hline V4 & Tamin Synthetic (Artificial Vinegar) & Industry & Malaysia & Halal Logo \\
\hline V5 & Khall Sakanjabeen Botanical drinks (Formula Vinegar) & Industry & Malaysia & Halal Logo \\
\hline V6 & Narcissus (Rice Vinegar) & Industry & China & Non-Halal Logo \\
\hline V7 & Wan Ja Shan (Rice Vinegar) & Industry & Taiwan & Non-Halal Logo \\
\hline V8 & Mizkan Sushi Vinegar (Rice Vinegar) & Industry & Japan & Non Halal Logo \\
\hline V9 & Heinz All (Natural Distilled White Vinegar) & Industry & $\begin{array}{l}\text { Pittsburgh- Pennsylvania } \\
\text { (United States) }\end{array}$ & Non-Halal Logo \\
\hline $\mathrm{V} 10$ & Tiparos (Distilled White Vinegar) & Industry & Thailand & Halal Logo \\
\hline V11 & Bragg Organic Raw-Unfiltered (Apple Cider Vinegar) & Industry & United States & Non-Halal Logo \\
\hline $\mathrm{V} 12$ & SandW Premium (Apple Cider Vinegar) & Industry & United States & Non-Halal Logo \\
\hline V13 & Sahara (Apple Vinegar) & Industry & Malaysia & Non-Halal Logo \\
\hline V14 & Halawatussunnah Organic (Apple Cider Vinegar) & Industry & Turkey & Halal Logo \\
\hline V15 & Narcissus (Black Vinegar Yongghun Laogu) & Industry & China & Non-Halal Logo \\
\hline V16 & Cheong Chan (Black Vinegar) & Industry & Malaysia & Halal Logo \\
\hline V17 & Radix (Date Vinegar) & Industry & Malaysia & Non-Halal Logo \\
\hline V18 & Fars (Date Vinegar with honey) & Industry & Malaysia & Halal Logo \\
\hline V19 & Al-Fasal (Pomegranate Vinegar) & Industry & $\begin{array}{l}\text { Middle East Product } \\
\text { (Imported and Packed By } \\
\text { Malaysia Manufacture } \\
\text { Middle East Product } \\
\text { (Imported and Packed By } \\
\text { Malaysia Manufacture) }\end{array}$ & Halal Logo \\
\hline $\mathrm{V} 21$ & Tesco (Malt Vinegar) & Industry & United Kingdom & Non-Halal Logo \\
\hline $\mathrm{V} 22$ & Alce Nero Organic (Balsamic Vinegar of Modena) & Industry & Italy & Halal Logo \\
\hline V23 & Vinigen (Rose Vinegar) & Industry & Taiwan & Non-Halal Logo \\
\hline V24 & $\begin{array}{l}\text { Petitzel Fruity Small Indulgency (Fruit Vinegar for } \\
\text { Drink) }\end{array}$ & Industry & Taiwan & Non-Halal Logo \\
\hline V25 & Vinigen (Pineapple Vinegar) & Industry & Taiwan & Non-Halal Logo \\
\hline
\end{tabular}

time-of-flight mass spectrometer (Leco Software). Each sample $(1 \mu \mathrm{L})$ was injected into an Agilent 7890 Gas Chromatography system equipped to a Pegasus Time of Flight (tof)-Mass Spectrometer detector (Leco, St. Joseph, MI, USA). Compounds were separated on an Rtx -5MS capillary column ( $30 \mathrm{~m} \times 0.25 \mathrm{~mm}$; film thickness, $0.25 \mu \mathrm{m}$ ). Helium carrier gas was used at a constant flow rate of $1.2 \mathrm{~mL} / \mathrm{min}$. The temperature program for metabolome analysis started with a $70^{\circ} \mathrm{C}$ for $1 \mathrm{~min}$ and followed by temperature ramping of $5^{\circ} \mathrm{C} / \mathrm{min}$ to a final temperature of $100^{\circ} \mathrm{C}$ in split mode, which was maintained for $1 \mathrm{~min}$. The acquisition rate was set to 30 spectra per second with the mass range of $20-1000 \mathrm{~m} / \mathrm{z}$. MS Pegasus-IV system (LECO, St. Joseph, USA) equipment with a liquid nitrogen quad-jet modulator and
CTC CombiPal Autosampler (CTC Analytics, Carrboro, NC, USA) was used in this study. The analysis was carried out in triplicate.

\subsection{Analysis of $p H$ content}

The $\mathrm{pH}$ of all vinegar samples was measured using $\mathrm{pH}$ meter (Fisher Science) was used to measure the $\mathrm{pH}$ of the vinegar samples. $\mathrm{pH}$ meter was calibrated prior used by using different buffer at $\mathrm{pH} 4.01, \mathrm{pH} 7.01$ and $\mathrm{pH} 10.01$ to check the accuracy of the instrument. Then, the $\mathrm{pH}$ electrode was placed into the $10 \mathrm{~mL}$ vinegar sample in a beaker at room temperature $\left(25^{\circ} \mathrm{C}\right)$ and the reading was recorded. All the result was recorded in triplicate and the average value was determined. 


\section{Results and discussion}

Vinegar is one of the oldest traditional foods produced through the fermentation process. Generally, Muslim consumers believe that all vinegar is categorized as halāl product, and it is classified as one of the favourite food of the Prophet Muhammad (P.B.U.H). However, the status hukm of vinegar is still uncertain since the presence of alcohol and concentration of an acetic acid reflect the halalness of a product. Vinegar is an acidic liquid, a fermentation product that contains acetic acid and alcohol as well as trace elements and flavoring. It was produced by the fermentation process either slowly or rapidly and the content depends on the substrate and the original ingredients used. Vinegar produced through the fermentation of ethanol and alcohol using bacteria to break down the ethanol into byproducts including acetic acid. Since the presence of alcohol and concentration of an acetic acid reflect the halalness of a product, therefore, ascertainment of alcohol and acetic acid content is necessary.

\subsection{Islamic approach to Halāl vinegar}

In general, Islam recognizes vinegar as a halāl food and commonly used as an idām (condiment) that is ideal for health and digestion (al-Subkī, 1984), it is also considered as a sunnah food that is favored by the Prophet Muhammad (P.B.U.H). However, Prophet Muhammad (P.B.U.H) did not particularly mention the method of making it, the source used in the manufacturing process, the storage method, the preparation method and the required fermentation time until it becomes vinegar. In the absence of clear guidance from the Prophet, there are traders who sell their products even though the vinegar are still in the takhammur state: which is the state where sugar changes into alcohol. The state of takhammur in the manufacturing of vinegar begins after the maximum period in the manufacture of nabidh.

Nabidh is a type of beverage produced from the fruit juice (Ibn Manzūur, 1997). It is also made from the soaking of dates, raisins, honey, wheat, cereals and so on (Ibn Mūsā, 2003; Ibn Abī Ḥâtim, 2006). A halāl nabidh is called nabidh ghair muskir in contrast to the haram nabidh; where it is called nabidh muskir or also known as khamr and it can be intoxicating (Al-'Ainī, 2001; AlNawawī, 2008). Nabidh ghair muskir or haläl nabidh is made from the extraction or soaking of dates, raisins in the period of permissible fermentation, while nabidh muskir or harām nabidh is produced during the fermentation period which exceeds the allowed period by sharia. The production of nabidh requires fermentation periods to allow the sugar content contained in the raw materials to be soluble and mixed with water. The duration of its fermentation provider can be divided into two parts, the minimum and maximum duration.

The minimum required time for nabidh fermentation is not more than 12 hours, which is between 8-12 hours only. There are some hadiths that explain that the Prophet Muhammad (P.B.U.H) drink nabidh at midnight when he prepared it at night and when the nabidh is prepared during the daytime, the Prophet Muhammad will drink it at night. The hadiths are as follows:

'A'isha reported: We prepared nabidh for Allah's Messenger in a water skin, the upper part of which was tied and it (the water skin) had a hole (in its lower part). We prepared the nabidh in the morning and he drank it in the evening and we prepared the nabidh in the night, and he would drink it in the morning. (Sahịh Muslim, Book 23, Hadith no.4977).

The maximum period allowed in the extraction/ consumption of nabidh is three and a half days as stated in the following hadith.

Based on these hadiths, the minimum level of alcohol can be produced before reaching the level on which is considered to be khamr is between 8 and 12 hours, while the period that exceeds that period is at the evening of the third day or in other words, 72 hours is considered the maximum permissible time to drink nabidh, at that time nabidh can be used as long as it tastes sweet, unchanged and not bubbling or boiling (AlNawawi, 1996$)$, but after the third day the Prophet did not drink it because it was feared that it contained high alcohol and could be harmful to health. In this case, the process of formulation of khamr has begun and can be categorized as the takhammur process, at this stage the product produced will be khamr and if the product is used at this time, it is considered harām. This is because it is still in the second process of fermentation or in other words it is entering the state of khamr.

However, the state of takhammur in vinegar preparation takes a longer process than the fermentation process to produce nabidh and the state of takhallul in vinegar preparation is longer than fermentation process to produce khamr that can last for months and even a year (Budak et al., 2014). Therefore, there is a mistake in determining the end of this takhammur process. The takhammur process will end when it enters the takhallul level which is the change of alcohol to acetic acid (vinegar). but the main thing to observe is that in this takhallul process, there is also a change that leads to shubhah, if the takhallul process is still early due to the conversion of alcohol to acetic acid that has not changed as a whole, the perfect takhallul process occurs when the whole alcohol content has turned into acetic acid. To find 
out the exchange, the tahawwul method is needed to ensure that any change is applicable to the product and its law.

\subsection{Science approach to test the Halalness of vinegar}

In the science perspective, vinegar $\left(\mathrm{CH}_{3} \mathrm{COOH}\right)$ is a chain that has a hydroxyl group $(-\mathrm{OH})$ bonded to a carbon atom where the carbon atom is also bound to hydrogen atoms and or to other carbon atoms. Vinegar is a chemical liquid that has a very close relationship with alcohol (R-OH), because it is produced by ethanol oxidation process $\left(\mathrm{CH}_{3} \mathrm{CH}_{2} \mathrm{OH}\right)$ by vinegar bacteria or also called acetic acid bacteria (AAB) of the genus Acetobacter that added to an alcoholic liquid such as wine, apples and beers, $\left(\mathrm{C}_{2} \mathrm{H}_{5} \mathrm{OH}\right)$ into acetic acid (Bhat et al., 2014). Physical and chemical properties of vinegar are almost identical to alcohol, in the form of noncolored liquids, with a very strong and sharp smell, volatile and easily inhaled and have a sour taste with $\mathrm{pH}$ or acid content between $2.40-3.40$ while cider vinegar is 3.10 (USFDA / CFSAN, 2007).

Acetic acid, Ethanoic acid or acid vinegar is a chemical compound of organic acids known as sour flavor in food. Vinegar has a $\mathrm{C}_{2} \mathrm{H}_{4} \mathrm{O}_{2}$ empirical formula. This formula is often written in the form of $\mathrm{CH} 3-\mathrm{COOH}$, $\mathrm{CH}_{3} \mathrm{COOH}$ or $\mathrm{CH}_{3} \mathrm{CO}_{2} \mathrm{H}$. Pure acetic acid (called glacial acetic acid) is colorless, hygroscopic liquid, and has a frozen point of $16.7^{\circ} \mathrm{C}$. Acetic acid is one of the carboxylic acids (R-COOH), an organic compound containing a carboxyl group $(\mathrm{COOH})$, in which the hydroxyl group (-OH) is directly affixed to the carbonyl group $(\mathrm{C}=\mathrm{O})$. Vinegar is the simplest acid after formic acid $(\mathrm{HCOOH})$ followed by Propionic acid $\mathrm{CH}_{3} \mathrm{CH}_{2} \mathrm{CO}_{2} \mathrm{H}$ which exists as a liquid at room temperature (Myers, 2007).

In general, vinegar can be formed, and modified in various ways, it is produced naturally and manmade from natural ingredients such as apples, bananas, rice and dates or from wine and apple cider (De Rovira, 2008) it can be understood as a product produced from cider, but specifically the vinegar cannot be formed directly from the cider, in other words, it is impossible to change directly into vinegar. Sugar compounds must first change into alcohol, through the fermentation process and then the alcohol will turn into acetic acid (Chen et al., 2016). With this statement, it is also understandable that the vinegar produced from rum, wine, whiskey or other alcoholic beverages require only one level: the changing stage from alcohol to acetic acid. Therefore, vinegar produced from alcoholic beverages can be produced directly from this fluid (Patel and Pandya, 2015). But alterations of alcoholic beverages such as wine and whiskey are valid through the chemical process in which ethyl alcohol turns into acetic acid. The changing process also involves bacteria known as Acetobacter (a.k.a. the vinegar bacteria) into acetic acid $(\mathrm{CH} 3 \mathrm{CO} 2 \mathrm{H})$ through oxidation (Tan, 2005).

In Islam, a product can be categorized as halāl if the product is originated from halāl ingredients, manufactured according to the halāl standards towards and at the end of the manufacturing process; a halāl product. Therefore, even vinegar can be produced from wine, but the halāl status is still uncertain. Although each vinegar product contains more than 90 different compounds such as hydrocarbons, carbonyls, esters, tartaric acid, citric acid, lactic, malic and other organic acids, there are two components that are the main focus of this study, namely alcohol and acetic acid. A product is not called vinegar unless the product had undergone the process of fermentation of the alcohol. Other than that, the vinegar should also contain acetic acid as the main component giving the sour taste in vinegar, but the acidity of a vinegar product must meet the standards prescribed by the law of nutrition especially the Malaysian food laws.

Analytical content of the acetic acid and alcohol are obtained by using High-Throughput Gas Chromatography with Time-of-Flight Mass Spectrometer Pegasus Time of Flight (tof) detector (Leco, St. Joseph, MI, USA) and Headspace Sampler (HS-10) chromatograph gas coupled with flame ionization detector (GC FID-2014) Shimadzu Corporation of Japan had found that acetic acid and ethanol content in vinegar products are different according to the product category and type of vinegar produced as portray in Figure 1 and Table 2.

\subsection{Analysis of acetic acid content}

In general, vinegar is a product that contains acetic acids, the contents of acetic acid vinegar is different according to the type and source of its preparation. Acetic acid is a major component of vinegar products, and it is a major component of vinegar that can give a sour taste to the product. Malaysia Food Regulations 1985 prescribes the contents of acetic acid in vinegar to contain no less than $4 \%$ volume for each weight of acetic acid (Malaysia Food regulation, 1985). This provision is also a resolution prescribed by the United States Food and Drug Administration (FDA). The higher the percentage of acetic acid found in the vinegar then it will affect the level of reduction in the percentage of alcohol content in vinegar. From the results obtained, most vinegar contained less than $4 \%$ of acetic acid. The highest is Fars Date Vinegar with honey with $0.032 \%$ then SandW Premium Apple Cider Vinegar with $0.029 \%$, followed by Alce Nero Organic Balsamic 


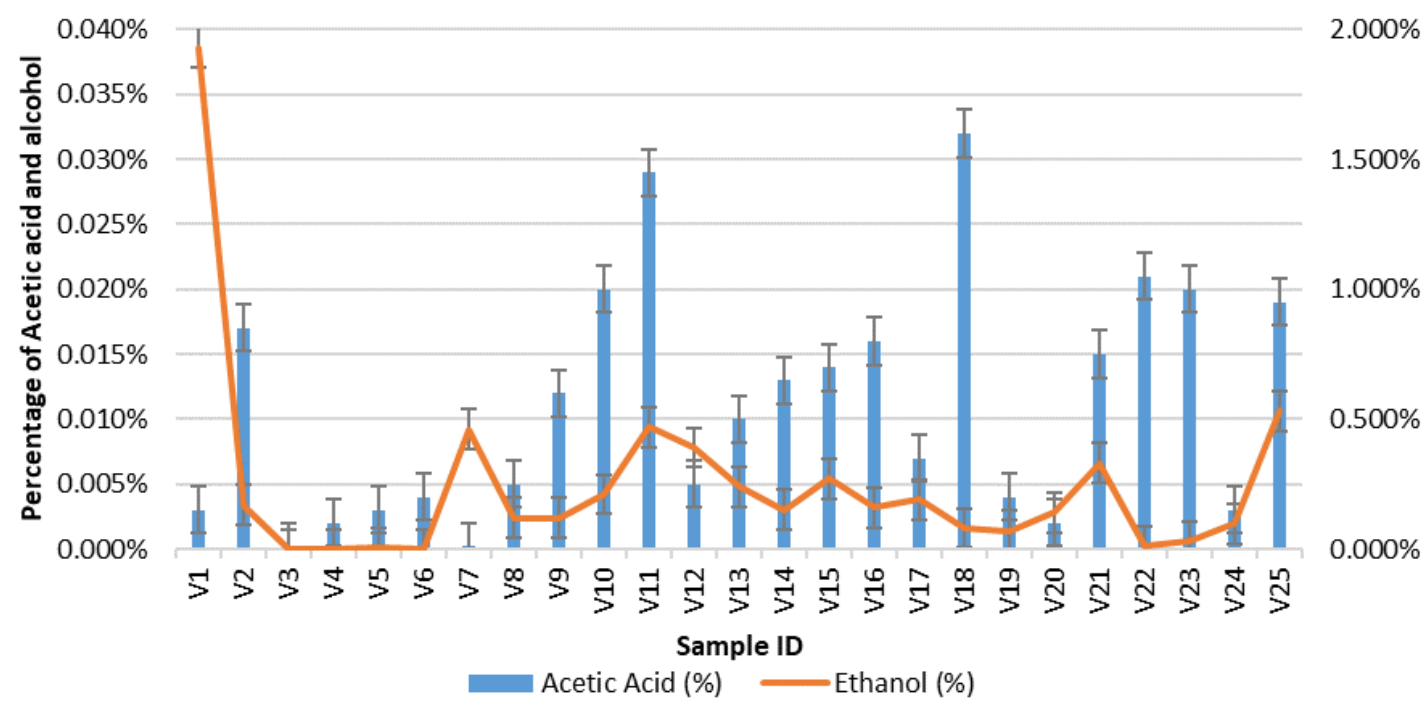

Figure 1. The percentage of alcohol and acetic acid in vinegar

Table 2. 25 Types of vinegar and content of alcohol and acetic acid (\%)

\begin{tabular}{ccccc}
\hline No. & Sample ID & Amount of Alcohol (\%) & Amount of Acetic acid (\%) & pH value \\
\hline 1 & V1 & $1.93 \%$ & $0.00 \%$ & $2.91 \pm 0.02$ \\
2 & V2 & $0.17 \%$ & $0.02 \%$ & $2.83 \pm 0.01$ \\
3 & V3 & Not Detected & $0.00 \%$ & $2.41 \pm 0.01$ \\
4 & V4 & Not Detected & $0.00 \%$ & $2.59 \pm 0.01$ \\
5 & V5 & $0.01 \%$ & $0.00 \%$ & $2.86 \pm 0.01$ \\
6 & V6 & Not Detected & $0.00 \%$ & $2.85 \pm 0.01$ \\
7 & V7 & $0.46 \%$ & $0.00 \%$ & $3.06 \pm 0.01$ \\
8 & V8 & $0.12 \%$ & $0.01 \%$ & $2.75 \pm 0.01$ \\
9 & V9 & $0.12 \%$ & $0.01 \%$ & $2.77 \pm 0.02$ \\
10 & V10 & $0.21 \%$ & $0.02 \%$ & $2.62 \pm 0.01$ \\
11 & V11 & $0.39 \%$ & $0.01 \%$ & $3.11 \pm 0.01$ \\
12 & V12 & $0.47 \%$ & $0.03 \%$ & $1.82 \pm 0.01$ \\
13 & V13 & $0.24 \%$ & $0.01 \%$ & $2.49 \pm 0.01$ \\
14 & V14 & $0.15 \%$ & $0.01 \%$ & $3.88 \pm 0.01$ \\
15 & V15 & $0.27 \%$ & $0.01 \%$ & $3.22 \pm 0.01$ \\
16 & V16 & $0.16 \%$ & $0.02 \%$ & $2.68 \pm 0.01$ \\
17 & V17 & $0.19 \%$ & $0.01 \%$ & $2.49 \pm 0.03$ \\
18 & V18 & $0.08 \%$ & $0.03 \%$ & $3.10 \pm 0.01$ \\
19 & V19 & $0.07 \%$ & $0.00 \%$ & $2.76 \pm 0.01$ \\
20 & V20 & $0.14 \%$ & $0.00 \%$ & $2.66 \pm 0.01$ \\
21 & V21 & $0.33 \%$ & $0.02 \%$ & $3.06 \pm 0.01$ \\
22 & V22 & $0.01 \%$ & $0.02 \%$ & $3.22 \pm 0.00$ \\
23 & V23 & $0.03 \%$ & $0.02 \%$ & $2.76 \pm 0.00$ \\
24 & V24 & $0.10 \%$ & $0.00 \%$ & $3.00 \pm 0.01$ \\
25 & V25 & $0.53 \%$ & $0.02 \%$ & $2.71 \pm 0.01$ \\
\hline
\end{tabular}

Vinegar of Modena with $0.021 \%$ while the lowest is Ikhwan artificial synthetic vinegar with $0.0002 \%$ and Wan Ja Shan rice vinegar with $0.0002 \%$.

\subsection{Analysis of the contents of ethanol}

Alcohol is an organic substance that is formed when hydroxyl group is substituted for a hydrogen atom in a hydrocarbon, it is an intoxicating liquid found in liquor (Baharom, 2007), and this liquid is commonly referred to as ethanol which is the main alcohol content contained in alcoholic beverages, produced through the process of fermentation of sugar by using yeast. Ethanol is a chemical liquefaction that can cause diffusion, the structure of the ethanol formula is $\mathrm{C}_{2} \mathrm{H}_{3} \mathrm{OH}$. Ethanol is produced through fermentation; it is used in intoxicating beverages as well as for industrial purposes by mixing gasoline to make gasohol called ethyl alcohol or grain alcohol (Solar Energy Research Institute, 1982). Alcohol is one of the most controversial topic debated among Muslims as it is one of the things that are prohibited in the Qur'an (Bonne and Verbeke, 2008), alcohol is often referred to as khamr which is banned in Islam, but the term alcohol is also often used when referring to the functional group of alcohol, one of which is ethanol; a major psychoactive component in alcoholic beverages. It 
is a component that comes naturally in fruits and fermented products such as vinegar (Najiha and Wan Nadiah, 2014). Therefore, there is a contradiction between fuqaha' regarding its function. Some scholars allow ethanol to be used in food processing based on the concept of 'umūm al-balwa (widespread affliction that virtually difficult to avoid) which is a difficult test to eliminate or could not be prevented (Abd Razak and Ramli, 2018) but others argue that ethanol status is the same as khamr that is prohibited to be used by the Muslims (Ab Ghani and Ismail, 2010). However, too little ethanol content is permissible as additives to foods used as dyes, preservatives, emulsifiers and anti-acid based on al-istihlak concepts which negate the small percentage of najs with the amount of clean and pure dominant material within a product (Fiqh-Medical Seminar, 1997).

In the view of Islam, alcohol is a liquid that is forbidden to be used by Muslims without any purpose and reasonable reason for being harmful to health because alcohol can also lead to something bad because it can eliminate mindfulness and sensible reasoning and eliminating sanity that can be categorized as khamr things that are illegal and prohibited in Islam (AlȘan'ānī, 2016). Although, each alcoholic beverage contains alcohol, but not all alcohol is illegal (harām). Alcohol obtained from the process of winemaking is illegal and unclean while the alcohol obtained not through the process of making alcoholic beverages is permitted, but it is not permitted to consume in its original form because it is harmful. Therefore, any form of soft drinks made with no intentions to produce alcohol or contains alcohol under $1 \% \mathrm{v} / \mathrm{v}$ level can be consumed, while soft drinks made with the intention of making wine and produced the same way in winemaking, either containing a small or a little alcohol or distilled alcohol is illegal (harām) (JAKIM, 2015). In this case, JAKIM has determined that the content of alcohol in any kind of soft drink must comply with the prescribed standards which is not to exceed $1 \% \mathrm{v} / \mathrm{v}$ while for food or drinks that contain flavoring or dye that contain alcohol for the purpose of stabilization is permissible to be used if the alcohol is not produced from the process of making wine and the quantity of alcohol in the final product must not be intoxicating and the content must not exceed $0.5 \%$ (JAKIM, 2015).

Fundamentally, the determination of the halal of vinegar is not specifically mentioned in the food law (diet law) and fatwa. It was never mentioned clearly about the percentage of the alcohol content. The Food Regulations 1985 only stated that vinegar, in general, must be the liquid result prepared from the fermentation of the alcohol and followed by the fermentation of the acetate of any suitable food, vinegar shall also contain not less than $4 \%$ volume for each acetic acid weight and shall not contain any mineral acid. The determination of alcohol content is only stated in the Food Regulations 1985 which is in regulation number 361 (1). The general standards for alcoholic drinks are as follows:

"Alcoholic beverages must consist of liquors containing more than 2 per cent of volume for each volume of alcohol and include standard food prescribed in the following regulations: 362 to 384,386 and 386A but not including litigation spirits or any liquor or any preparations containing more than 2 percent volume of each recognized volume of alcohol has a change in nature ".

Apart from that, the resolution of alcohol content is also stated in a fatwa that has been decided by the Muzakarah of the National Council for Islamic Religious Affairs of Malaysia on the issue of Alcohol in Food, Drinks, Fragrances and Medicines (2011). The fatwa states:

"Soft drinks that are processed or made with not intended to produce alcohol and have alcohol under $1 \% \mathrm{v} / \mathrm{v}$ should be (can be) consumed, while soft drinks made with the intention of making wine and have similar process of making wine, either contain more or fewer alcohol or distilled alcohol is illegal to drink. Food or beverages containing flavors or dyes containing alcohol for stabilization purposes is permitted if the alcohol is not produced by the process of winemaking and the quantity of alcohol in the final product is not intoxicating and the alcohol content does not exceed $0.5 \%$ ".

Food Regulations 1985 and the Muzakarah of the National Council for Fatwa Committee for Islamic Religious Affairs did not specify the specific content of alcohol allowed in vinegar, although the Muzakarah of the National Council for Fatwa Committee for Islamic Religious Affairs had decided on the vinegar resolution on the $76^{\text {th }}$ muzakarah. However, the fatwa did not specify the permissible alcohol content in vinegar.

In the absence of resolution on the permitted alcohol in vinegar products, it is difficult to classify vinegar from halāl to harām. Therefore, the concept of tahawwul can be used as an alternative determination of the law or $h u k m$ of vinegar by looking at the content of alcohol and acidic acids present in vinegar products. The results showed that each vinegar product contains ethanol with a different percentage of ethanol depending on the type of vinegar and its source. The study found that the percentage of alcohol in traditional vinegar and industry is different. The highest percentage of alcohol was found in the non-halāl Palm Vinegar (1.9\%), which is the highest alcohol content of all types of vinegar in 
Malaysia. On the other hand, the highest percentage of alcohol in industrial vinegar is found in Vinigen Pineapple Vinegar with a non-halāl logo; which is 0.53 .

\subsection{Analysis of the contents $p H$}

Vinegars are produced from cider, grapes or wine, sucrose, glucose, malt, or any sugar-containing material that can be converted by successive alcoholic and acetous fermentation. Petsiou et al. (2015) stated that vinegar is good for increased glucose uptake (Mitrou et al., 2015) and improved insulin sensitivity. The $\mathrm{pH}$ value indicates the acid strength in substances including food and drinks (Underhill, 1989). $\mathrm{pH}$ value is important to categorize vinegar based on the acid strength. The lower the $\mathrm{pH}$ value shows high level of acidity. Acetic acid is the major acid in vinegar. Acetic acid gives the global standards of taste, distinguishes vinegar and specify minimum acidity levels for vinegar. $\mathrm{pH}$ scale is widely recognized measurement of the strength of an acid and base. The total acidity of vinegar is expressed as acetic acid. Acetic acid is one of the organic acid and a monocarboxylic acid. Acidification is an important factor to limit the growth of spoilage microorganisms in fermentation such study by Lingham et al. (2013) addition of citric acid and acetic acid each reduced the growth of Enterobacteriaceae. Because of acetic acid content and low $\mathrm{pH}$, vinegar is used as a preservative for both domestic use and in the food industry

As depicted in Table 2, different vinegar sample have different $\mathrm{pH}$ value but the majority are between 2.5 3.0 except sample 12, the $\mathrm{pH}$ value is 1.82 . All were in the right value of $\mathrm{pH}$ for vinegar which is from 2.00 to 3.50. It is expected that a faster reduction in $\mathrm{pH}$ will indicate a higher breakdown of the substrates, and concomitantly leading to a more rapid increase of ethanol content. Based on Table 2, sample 12 fulfil the statement with $0.47 \%$ and $0.029 \%$ of the highest alcohol and acetic acid content respectively. $\mathrm{pH}$ value reduced with the production of lactic acid during fermentation. Synthetic vinegar is a vinegar produced by using chemicals such as sample 3 and 4 . Based on the $\mathrm{pH}$ result reported, the vinegar that chemically produced is less acidic with the one that produced from the natural sources in contra with Jamaludin et al. (2017) that synthetic is more acidic compared to vinegar from fruits. Vinegar from natural sources was less acidic however some same type of vinegar has significant different $\mathrm{pH}$ value might due to the process involved in the production of vinegar such as sample 17 and 18 both from date.

Based on this study, the analysis on 25 samples of vinegar found in the Malaysian market, the researcher found that the whole vinegar is classified as halāl, the whole sample has surpassed the complete transformation process so that it does not leave any trace of alcohol except at the rate allowed by the National Fatwa Council of Malaysia, but there are two types of vinegar that are classified as illegal vinegar (harām) because the vinegar is still in the process of takhammur so it contains alcohol level that is not allowed by the sharia and Malaysia National Fatwa Council (Table 2). In this case, the vinegar is still in the process of tahawwul fasidd (uncomplete transformation) thus the resulting in illegal (fasid vinegar). Therefore, it can be concluded that the vinegar found in the Malaysian market can be categorized into two main groups namely halāl vinegar and harām vinegar.

\section{Conclusion}

In conclusion, the product produced through the fermentation process takes a long period in ensuring that the product is produced in a state of halalan tayyiban and free from intoxicant alcohol. To determine the degradation of a product produced through the fermentation process, it is necessary to have a shummūl (comprehensive) concept from the beginning of the manufacturing process until the final product. The application of this tahawwul application can be used as an alternative source for determining the dehydration of a product especially the product produced through the fermentation process, this concept can contribute to some more accurate findings as any changes in the fermentation process will lead to the different legal status of a product. Hence, these findings can directly assist various parties involved in issuing illegal halāl law on the present day.

\section{Conflict of Interest}

The authors declare no conflict of interest.

\section{References}

Ab Ghani, A. and Ismail, M.S. (2010). Penentuan Piawaian Alkohol Dalam Makanan Yang Dibenarkan Dari Pespektif Islam. Jurnal Fiqh, 7, 277-299.

Abd Razak, M.A. and Ramli, M.A. (2018). The Concept 'Umūm al-Balwā in Pardoned Impurities Context (al -najāsah al-ma'fu 'anhā) in the Book of Al-Ashbāh wa al-Nazāir of Jalaluddin al-Suyuti. Online Journal Research in Islamic Studies, 4(3), 1-11. https://doi:10.15364/ris17-0403-01

Al-'Ain̄̄, B.A.M. (2001). 'Umdah al-Qārī Sharḥ Saḥịh al -Bukhārī. Beirut: Dār al-Kotob al-'Ilmiyah.

Al-Ghazālī, A.Ḥ.M. (2006). Majmū'ah Rasāil al-Imām al-Ghazālì. Beirut: Dār al-Kotob al-'Ilmiyah. 
Amsīwìț, I.A.M. (2016). Al-Tahawwul fì Niz̄ām al-Ithbāt al-Jināì. Cairo: Ain Shams University, PhD Dissertation.

Al-Nawawī, A.Z.Y. (2008). Al-Majmū' Sharh alMuhadhdhab. Jeddah: Maktabah al-Irshad. (1996). Al-Minhāj Fì Sharh Saḥịh Muslim bin al-Hajjājj. Beirut: Dār al-Khair.

Al-Ṣan'ān̄̄, M. I. (2016). Subūl al-Salām Sharh Bulūgh al-Marām min Adillah al-Ahkām. Beirut: Sharikah Dār al-Arqām bin Ab̄̄ al-Arqām.

Al-Subkī, M.K. (1984). Al-Dīn al-Khāliș Aw Irshād alKhalq Ilā Dìn al-Haqq. Cairo: Al-Maktabah AlMaḥmūdiah al-Subkiyah.

Al-Tahānawī, 'A.M.'A. (1996). Mawsū'ah Kashāf alIstilāhāt al-Funūn Wa al-'Ulūm. Lubnan: Maktabah Lubnan Nāshirūn.

Al-Zuhạaylī, W.M. (1985). Al-Fiqh al-Islām Wa Adillatuh. Damshiq: Dār al-Fikr.

Baharom, N. (2007). Kamus Dewan. $4^{\text {th }}$ ed. Kuala Lumpur: Dewan Bahasa dan Pustaka.

Bhat, S.V., Akhtar, R. and Amin, T. (2014). An Overview on the Biological Production of Vinegar. International Journal of Fermented Foods, 3(2), 139155. https://doi: 10.5958/2321-712X.2014.01315.5

Bonne, K. and Verbeke, W. (2008). Muslim consumer trust in halal meat status and control in Belgium. Meat Science, 79(1), 113-123. https://doi: 10.1016/ j.meatsci.2007.08.007

Budak, N.H., Aykin, E., Seydim, A.C., Greene, A.K. and Guzel-Seydim, Z.B. (2014). Functional Properties of Vinegar. Journal of Food Science, 79(5), 757-764. https://doi.org/10.1111/1750-3841.12434

Chen, H., Chen, T., Giudici, P. and Chen, F. (2016). Vinegar Functions on Health: Constituents, Sources, and Formation Mechanisms. Comprehensive Reviews in Food Science and Food Safety, 15(6), 1124-1138. https://doi.org/10.1111/1541-4337.12228

Codex Alimentarius Commision. (1987). Proposed Draft Revised Regional Standard for Vinegar (At Step 3 of the Procedure) Codex Stan 162-1987. Retrieved on February 28, 2019 from Codex Alimentarius Commision http://www.fao.org/tempref/codex/ Meetings/CCEURO/CCEURO22/CL00_18e.pdf

Deedat, A. (1991). Al-Khamr Bayna al-Masīhiyyah Wa al-Islām. (Trans). Mukhtār, M. Cairo: al-Mukhtār alIslāmī.

De Rovira, D.S.R. (2008). Dictionary of Flavors. $2^{\text {nd }}$ ed. New Jersey: Blackwell Publishing-John Wiley and Sons Ltd.

Fiqh-Medical Seminar. (1997). Transformation, Additives in Food and Medicine and Substances,
Actions that Nullify the Fasting. Retrieved on February 28, 2019 from Fiqh-Medical Seminar http://www.islamset.com/bioethics/9thfiqh.html

Ghanem, S.A.K. (2014). Prohibited and impure (Najis) animals offered as examples for purified Istihala in sharia perspective [blood plasma, wine (acidification of wine as example), "impure and prohibited feed" (pig feed of farmed fish as example)]. In Kuwait: 3rd Gulf Conference on the Halal Industry and its Services. Palestine: Research of Fiqh, legislation and fundamentals Jerusalem University.

Hailu, S., Admassu, S. and Jha, Y.K. (2012). Vinegar Production Technology - An Overview. Food Process Engineering Program, Ethiopia: Addis Ababa Institute of Technology (AAiT), Addis Ababa University.

Ibn Ab̄̄ Hāatim, 'A.M. (2006) Kitāb al-'Ilal. Riyadh: Maktabah Malik al-Fahd.

Ibn Manẓūr, M.M. (1997). Lisān al-'Arab. Cairo: Maktabah Tawfiqiah.

Ibn Mūsā, M. 'A. (2003). Qurrat 'Ain al-Muḥtāj fì Sharh Muqaddimah Șah̄ịh al-Imām Muslim ibn al-Hajājj. Dammām: Dār Ibn al-Jawzī.

Jabatan Kemajuan Islam Malaysia (JAKIM). (2015). Kompilasi Pandangan Hukum Muzakarah Jawatankuasa fatwa Majlis Kebangsaan Bagi Hal Ehwal Ugama Islam Malaysia. $5^{\text {th }}$ ed. Malaysia: Jabatan Kemajuan Islam Malaysia (JAKIM).

Jamaludin, M.A., Hashim, D.M., Rahman, R.A., Ramli, M.A., Majid, M.Z.A., Othman, R. and Amin, A. (2017). Determination of permissible alcohol and vinegar in Shariah and scientific perspectives. International Food Research Journal, 23(6), 27372743.

Lingham, T., Besong, S., Ozbay, G. and Lee, J.L. (2013). Antimicrobial Activity of Vinegar on Bacterial Species Isolated from Retail and Local Channel Cat Catfish (Ictalurus punctatus). Journal of Food Processing and Technology, 4(S11), 1-5. http://dx.doi.org/10.4172/2157-7110.S11-001

Malaysia Food Regulation. (1985). Arrangement of Regulations. Retrieved on February 28, 2019 from Malaysia Food Regulation 1985 http:// myco2.com.my/phocadownloadpap/

Govt_Act_Regulation/Malaysia\%20Food\% 20Regulation\%201985.pdf

Mitrou, P., Petsiou, E., Papakonstantinou, E., Maratou, E., Lambadiari, V., Dimitriadis, P., Spanoudi, F., Raptis, S.A. and Dimitriadis, G. (2015). Vinegar Consumption Increases Insulin-Stimulated Glucose Uptake by the Forearm Muscle in Humans with Type 2 Diabetes. Journal of Diabetes Research, 1, 1- 
7. https://doi.org/10.1155/2015/175204

Myers, R.L. (2007). The 100 most important chemical compounds: a reference guide. Westport, Connecticut: Greenwood Press.

Najiha, A.A. and Wan Nadiah W.A. (2014). Alkohol (Arak dan Etanol) dalam Makanan Halal. Jurnal Intelek, 9(1), 40-51.

Orey, C. (2009). The Healing Powers of Vinegar: A Complete Guide to Nature's Most Remarkable Remedy. New York: Kensington Publishing Corporation.

Patel, R. and Pandya, H.N. (2015). Production of Acetic Acid from Molasses by Fermentation Process. International Journal of Advance Research and Innovative Ideas in Education (IJARIIE) 1(2), 58-60.

Petsiou, E., Mitrou, P., Papakonstantinou, E., Maratou, E., Lambadiari, V., Spanoudi, F. and Dimitriadis, G. (2015). Acetic acid enhances insulin-stimulates glucose uptake by the forearm muscle in patients with type 2 diabetes. Diabetologia, 58(1), S254S255.

Riaz, M.N. (1997). Alcohol: The Myths and Realities. In Uddin, Z. (Eds). Handbook of Halal and Haram products, p.16-30. Richmond Hill, NY: Publishing Centre of American Muslim Research and Information.

Solar Energy Research Institute. (1982). Ethanol Fuels Reference Guide. $1^{\text {st }}$ ed. Colorado: Solar Energy Research Institute.

Tan, S.C. (2005). Vinegar Fermentation. Louisiana: University of Louisiana at Lafayette, MSc. Thesis.

Underhill J.E. (1989). pH without pain. Retrieved on January 09, 2020 from The Grapevine website: http://www.bcawa.ca/winemaking/ph.htm

United States Food and Drug Administration (USFDA) Centre for Food Safety and Applied Nutrition (CFSAN). (2007). Definitions: Adulteration with Vinegar Eels CPG Sec. 525.825 Vinegar. Retrieved on February 28, 2019 from FDA website: https:// www.fda.gov/regulatory-information/search-fdaguidance-documents/cpg-sec-525825-vinegardefinitions-adulteration-vinegar-eels

Wizārat al-Awqāf Wa Shuūn al-Islāmiyyah al-Kuwait. (1983). Al-Mawsūat al-Fiqhiyyat. $2^{\text {nd }}$ ed. Kuwait: Wizārat al-Awqāf Wa Shuūn al-Islāmiyyah alKuwait.

Zohri, A.N.A. and Etnan, M.M. (2000). Ethanol Production from Dates in Saudi Arabia on Industrial Scale. Mycobiology, 28(2), 76-81. https:// doi.org/10.1080/12298093.2000.12015727 